\title{
PENERAPAN METODE PEMBELAJARAN REWARD AND PUNISHMENT DALAM MENINGKATKAN PRESTASI BELAJAR MENGETIK SISTEM 10 JARI PADA SISWA KELAS X OTKP-1 SMK NEGERI 2 SELONG TAHUN PELAJARAN 2020/2021
}

\author{
Sabri \\ SMK NEGERI 2 SELONG \\ Email: 54b12i@gmail.com
}

\begin{abstract}
Abstrak
Tujuan penelitian ini untuk mengetahui penerapan metode reward and punishment dalam meningkatkan prestasi belajar materi pokok mengetik sistem 10 jari siswa kelas X Otomatisasi Tata Kelola Perkantoran SMK Negeri 2 Selong. Penelitian ini berjenis Penelitian Tindakan Kelas. Penelitian ini dilaksanakan dalam bentuk siklus sesuai dengan model Kemmis dan Mc Taggart yaitu tahap-tahap penelitian tindakan kelas untuk mencapai perubahan dan hasil yang diinginkan. Tahap-tahap yang dimaksud mulai dari tahap perencanaan, pelaksanaan, pengamatan dan refleksi. Berdasarkan hasil penelitian dan pembahasan yang telah diuraikan pada bab sebelumnya, maka dapat disimpulkan bahwa metod ereward and punishment dapat meningkatkan prestasi belajar mengetik system 10 jari pada siswa-siswi kelasX OTKP-1 SMK Negeri 2 Selong. Hal ini dibuktikan dari nilai keterampilan mengetik sistem10 jari dengan rata-rata pada prasiklus sebesar 70,06. Melalui kegiatan pembelajaran siklus I menggunakan metode reward and punishment pada mata pelajaran mengetik sistem 10 jari dapat meningkatkan rata-rata nilai siswa menjadi 74,0 dan pada siklus II rata-rata nilai siswa meningkat menjadi 80,2. Dimana pada nilai rata-rata siklus II sudah melampaui target yang ditetapkan sebesar 75. Sedangkan untuk hasil keterampilan siswa dengan persentase jumlah siswa yang mencapai KKM pada prasiklus sebesar $31 \%$ atau 10 siswa dari 32 siswa, siklus I siswa yang mencapai KKM sebesar 50\% atau 16 orang dari 32 siswa, dan pada siklus II siswa yang mencapai KKM sebesar 88\% atau 28 orang dari 32 siswa.
\end{abstract}

Kata Kunci : reward and punishment, prestasi belajar, mengetik

\begin{abstract}
The purpose of this study was to determine the application of the reward and punishment method in improving learning achievement of the subject matter of typing the 10 finger system of class X Office Administration Automation at SMK Negeri 2 Selong. This research type is Classroom Action Research. This research was conducted in the form of a cycle according to the model of Kemmis and Mc Taggart, namely the stages of classroom action research to achieve the desired changes and results. The stages in question start from the planning, implementation, observation and reflection stages. Based on the results of the research and discussion that have been described in the previous chapter, it can be concluded that the reward and punishment method can improve the learning achievement of the 10-finger typing system in class X OTKP-1 SMK Negeri 2 Selong. This is evidenced by the value of the 10-finger system typing skill with an average of 70.06 in the pre-cycle. Through learning activities in the first cycle using the reward and punishment method in the 10-finger typing system subject, it can increase the students' average score to 74.0 and in the second cycle the students' average score increases to 80.2. Where the average value of the second cycle has exceeded the set target of 75. As for the results of student skills with the percentage of students who achieved the KKM in the pre-cycle of $31 \%$ or 10 students out of 32 students, the first cycle of students who achieved the KKM was $50 \%$ or 16 students out of 32 students, and in the second cycle the students who achieved the KKM were $88 \%$ or 28 out of 32 students.
\end{abstract}

Keywords: reward and punishment, learning achievement, typing 


\section{PENDAHULUAN}

$\begin{array}{cccc}\text { (SMK) } & \begin{array}{c}\text { Sekolah } \\ \text { terdapat }\end{array} & \begin{array}{l}\text { Menengah } \\ \text { beberapa }\end{array} & \begin{array}{r}\text { Kejuruan } \\ \text { kompetensi }\end{array}\end{array}$ keahlian, salah satu diantaranya adalah kompetensi keahlian Otomatisasi dan Tata Kelola Perkantoran. Otomatisasi dan Tata Kelola Perkantoran merupakan salah satu kompetensi keahlian yang disiapkan untuk mencetak lulusan yang terampil dalam bidang perkantoran. Semua kegiatan bisnis maupun kegiatan pemerintahan tidak lepas dari aktivitas perkantoran, sehingga tenaga administrasi perkantoran banyak dibutuhkan. Salah satu kegiatan Administrasi yaitu suratmenyurat. Walaupun banyak teknologi komunikasi yang canggih, tetapi suratmenyurat di lingkungan perkantoran sangat dibutuhkan. Fungsi surat sebagai bukti fisik tidak akan pernah tergeser oleh teknologi digital.

Berkaitan dengan aktivitas suratmenyurat rangkaian belajar mengajar yang tidak kalah penting pada kompetensi keahlian Otomatisasi dan Tata Kelola Perkantoran adalah mata pelajaran Teknologi Perkantoran yang didalamnya terdapat materi pokok mengetik system 10 jari. Mengetik system 10 jari merupakan salah satu materi pokok Mata Pelajaran Teknologi Perkantoran yang bertujuan untuk membekali siswa dalam keterampilan mengetik 10 jari, siswa dapat memahami dan mempraktikkan posisi jarijari di huruf yang tepat, sehingga memudahkan dan mempercepat dalam melakukan pengetikan, maka siswa dapat menerapkan ilmu pengetahuan yang diperoleh dari bangku sekolah kedalam dunia kerja karena di dunia kerja dituntut untuk bekerja cepat dan akurat.

Berdasarkan observasi awal yang dilakukan pada tanggal 12 September 2020 diketahui bahwa prestasi belajar pada materi pokok mengetik system 10 jari masih rendah. Hal ini tercemin ketika pembelajaran berlangsung kegiatan-kegiatan yang dilakukan siswa mencerminkan motivasi dan prestasi belajar materi pokok mengetik sistem 10 jari rendah yaitu dilihat dari banyak siswa yang tidak mencatat saat guru memberikan materi dan kurang aktifnya siswa bertanya kepada guru, dan masih banyak ditemukan siswa yang tidak mengetik 10 jari dengan benar ketika sedang mengerjakan soal yang diberikan oleh guru. Kenyatannya disekolah siswa tidak dibekali dengan modul atau sumber belajar pendukung, sumber belajar siswa hanya dari catatan siswa itu sendiri yaitu berisi materi yang diterangkan oleh guru.

Ada beberapa hal yang menyebabkan siswa tidak semangat dalam mengikuti pembelajaran mengetik system 10 jari sehingga berdampak pada prestasi belajar siswa yakni siswa beranggapan mengetik menggunakan 10 jari terasa lebih lama dan mengetik dengan dua jari dirasa lebih cepat dan lebih mudah. Terdapat pula siswa yang belum mengenal computer dan pada saat di SMP belum diajarkan. Pembelajaran mengetik sistem 10 jari dilakukan selama $4 \mathrm{x}$ 45 menit yaitu guru menerangkan materi pelajaran kemudian guru memberikan penugasan kepada siswa tanpa dilakukan pengawasan oleh guru. Pengawasan guru yang minim, pemberian teguran dari guru yang kurang dan pemberian penghargaan berupa pujian, pada siswa yang mampu mengetik dengan cepat dan tepat, serta tidak adanya ketegasan dari guru untuk mengetik system 10 jari dengan benar membuat siswa menyepelekan dan mengetik dengan sembarangan.

Berdasarkan hasil wawancara dengan guru pengampu mata pelajaran otomatisasi perkantoran pada materi pokok mengetik system 10 jari, kendala- kendala yang dihadapi yaitu dalam hal alat pendukung yaitu komputer. Siswa belum terbiasa untuk mengetik 10 jari karena dibangku Sekolah Menengah Pertama (SMP) para siswa belum pernah diajarkan mengetik 10 jari dan untuk anak yang kurang mengenal computer cenderung lamban dalam mengetik, siswa yang lamban mengetik cenderung tidak mau mempelajari mengetik dengan menggunakan 10 jari dan cenderung lebih memilih menggunakan dua jari. Maka dari itu berpengaruh terhadap minat dan prestasi belajar peserta didikuntuk dapat mengetik dengan terampil dan tepat.

Peserta didik dalam mengikuti pembelajaran cenderung ingin segera menyelesaikan tugas mengetiknya dengan cepat tanpa memperhatikan mengetik system 10 jari secara benar, sebab dengan tugas yang banyak dan waktu yang kurang siswa beranggapan apabila menggunakan 10 jari 
akan menghabiskan waktu dan saat jam berakhir siswa belum selesai mengerjakan tugas, sehingga dalam proses pembelajaran mengetik sistem 10 jari tingkat keberhasilan dalam mengetik system 10 jari bukan hanya dilihat dari seberapa cepat peserta didik menyelesaikan tugasnya, melainkan peserta didik dapat menerapkan mengetik sistem 10 jari dengan benar.

Banyak faktor untuk membuat siswa termotivasi dalam belajar dan berprestasi salah satunya yaitu dengan memberikan penghargaan (reward) dan teguran atau hukuman (Punishment). Adanya metode yang sudah diterapkan oleh guru dan pemberian reward dan punishment diharapkan dapat menumbuhkan motivasi belajar siswa agar dapat mencapai prestasi yang lebih baik lagi.

Penulis dan guru berupaya meningkatkan prestasi belajar siswa melalui reward and punishment. Reward and punishment diterapkan didalam metode pembelajaran yang sudah dilaksanakan oleh guru. Penulis berkolaborasi dengan guru mata pelajaran otomatisasi perkantoran dalam hal meningkatkan prestasi belajar siswa, sehingga dengan adanya reward and punishment diharapkan siswa termotivasi dan terampil dalam mengetik 10 jari dan tidak hanya tugas dapat selesai tepat waktu tetapi posisi jari siswa sesuai dengan pedoman mengetik sistem 10 jari.

Oleh karena itu untuk meningkatkan prestasi belajar mata pelajaran Sistem Mengetik 10 Jari maka penulis melakukan penelitian dengan judul "Penerapan Metode Reward and Punishment Dalam Meningkatkan Prestasi Belajar Mengetik Sistem 10 Jari Siswa Kelas XOTKP-1 SMK Negeri 2 Selong".

\section{Tujuan Penelitian}

Tujuan penelitian ini untuk mengetahui penerapan metode reward and punishment dalam meningkatkan prestasi belajar materi pokok mengetik sistem 10 jari siswa kelas X Otomatisasi Tata Kelola Perkantoran SMK Negeri 2 Selong.

\section{Kerangka Pikir}

Keterampilan mengetik 10 jari adalah keterampilan yang sangat dibutuhkan bagi seorang administrator atau paling tidak bagi seorang yang menggunakan alat ketik (keyboard) untuk keperluan mengetik. Selain lebih cepat dalam mengetik karena tidak perlu melihat tombol-tombol pada keyboard, mengetik 10 jari juga lebih efisien dibandingkan mengetik dengan dua jari. Mengetik dua jari adalah mengetik yang hanya menggunakan kedua jari telunjuk dan tidak memfungsikan jari-jari yang lain. Mengetik dua jari tidak efisien karena disamping pengetik terfokus pada hasil output ketikan, mereka juga memperhatikan input atau masukan pada tombol keyboard.

Penulis akan mengkhususkan meneliti prestasi belajar mengetik sistem 10 jari siswa-siswi kelas $\mathrm{X}$ Otomatisasi dan Tata Kelola Perkantoran di SMK Negeri 2 Selong, mata pelajaran Teknologi Perkantoran.

Selama kegiatan pembelajaran materi pokok mengetik system 10 jari pada mata pelajaran Teknologi Perkantoran guru pengampu mata pelajaran hanya sebatas menerangkan cara-cara mengetik 10 jari melalui lisan (ceramah) dan melalui penugasan yaitu guru menjelaskan kemudian satu persatu siswa diberi tugas yang berupa huruf-huruf untuk diketik dengan menggunakan 10 jari. Guru hanya sebatas menerangkan dan memberi tugas tanpa ada pengawasan yang ketat. Menurut peneliti cara demikian akan membuat siswa menyepelekan dan tidak termotivasi untuk belajar sehingga berdampak pada beberapa siswa yang nilainya masih belum mencapai Kriteria Ketuntasan Minimal (KKM). Siswa hanya memikirkan tugasnya cepat selesai tanpa memikirkan aturan mengetik 10 jari dengan benar. Media yang digunakan guru yaitu guru sebatas menggunakan papan tulis yang berisi materi mengetik system 10 jari, kemudian siswa mencatatnya. Seharusnya agar siswa lebih semangat dan tertarik dalam belajar mengetik system 10 jari semua siswa dikelas perlu diberikan gambar mengenai bentuk jari yang diberi keterangan huruf sesuai dengan pedoman mengetik sistem 10 jari dibuat semenarik mungkin dan diberikan warna-warni yang berbeda pada setiap fungsi jari pada huruf di keyboard. Hal tersebut juga bertujuan agar siswa yang tidak mencatat mempunyai catatan, karena pada intinya mengetik system 10 jari ialah hafal tentang peletakan jari dikeyboard dan dapat mempraktekan. 
Berdasarkan landasan teori, metode reward and punishment untuk meningkatkan prestasi belajar mengetik system 10 jari. Metode reward and punishment adalah metode yang menerapkan system pemberian konsekuensi baik dan pemberian konsekuensi tidak baik sebagai upaya untuk memotivasi belajar siswa agar dapat meningkatkan prestasinya dalam mengetik system 10 jari dan tidak menggunakan mengetik dua jari. Berdasarkan permasalahan diatas maka dapat digambarkan alur kerang kapikir yang dapat dilihat melalui gambar

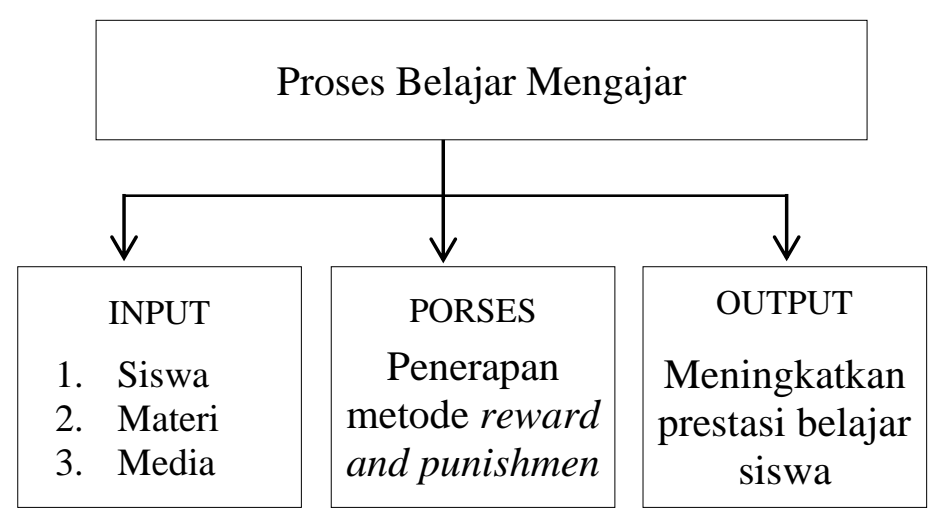

Gambar1. Alur Kerangka Pikir

\section{Hipotesis Tindakan}

Berdasarkan kerangka piker di atas, maka hipotesis tindakan dari penelitian ini adalah metode reward and punishment dapat meningkatkan prestasi belajar mengetik sistem10 jari pada siswa-siswi kelas $\mathrm{X}$ OTKP-1 SMK Negeri 2 Selong.

\section{METODE PENELITIAN}

\section{A. Setting Penelitian dan Objek Penelitian}

Pada penelitian tindakan kelas ini, peneliti memfokuskan penelitian pada upaya peningkatan hasil belajar siswa kelas $\mathrm{X}$ Otomaisasi dan Tata Kelola Perkantoran (OTKP) SMK Negeri 2 Selong dengan menggunakan metode Reward and Panishment. Tujuannya adalah untuk mengetahui efektifitas metode pembelajaran Reward and Panishment dalam upaya meningkatkan hasil belajar siswa, serta mengetahui seberapa besar peningkatan hasil belajar siswa menggunakan metode Reward and Panishment pada materi Mengetika 10 Jari.

Penelitian tindakan kelas ini dilaksanakan di SMK Negeri 2 Selong pada semester ganjil tahun pelajaran
2020/2021 yaitu pada tanggal 01 September 2020sampai dengan 31 Oktober 2020 sesuai dengan kalender pendidikan yang telah dibuat.

B. Subjek Penelitian

Pada penelitian tindakan kelas ini, dilaksanakan di SMK Negeri 2 Selong pada mata pelajaran Teknologi Perkantoran materi Aplikasi Pengolah Kata (Mengetik 10 Jari). Subjek penelitian adalah siswa kelas $\mathrm{X}$ Otomatisasi dan Tata Kelola Perkantoran (OTKP) tahun pelajaran 2020/2021 yang berjumlah 32 orang.

Dalam penelitian ini, guru yang mengajar di kelas $\mathrm{X}$ Otomatisasi dan Tata Kelola Perkantoran sekaligus bertindak sebagai peneliti, dalam pelaksanaannya dibantu oleh seorang teman sejawat yaitu Suharman, S.Pd. yang bertindak sebagai observer yang bertugas mengamati dan mencatat:

a) Aktivitas atau gaya mengajar guru/peneliti selama proses pembelajaran berlangsung pada mata pelajaran Teknologi Perkantoran materi Mengetik 10 Jari dengan menggunakan metode Reward and panishment. 
Vol. 10. No. 1. Tahun 2022

b) Aktivitas atau tingkah laku siswa selama proses pembelajaran Teknologi Perkantoran berlangsung pada materi Mengetik 10 Jari dengan menggunakan metode Reward and Panishment.

C. Desain Penelitian

Penelitian ini berjenis Penelitian Tindakan Kelas. Desain penelitian mengikuti prinsip dasar yang dikemukakan oleh Kemmis \& Taggart dalam SuharsimiArikunto (2008:16), "terdiri dari tahap-tahap: perencanaan (planning), tindakan (acting), pengamatan (observe), dan refleksi (reflect)". Tahapan-tahapan tersebut diikuti dengan perencanaan ulang jika diperlukan sampai tujuan penelitian tercapai.

Alur penelitian tindakan kelas ini dapat dilihat melalui gambar 2.yaitu:

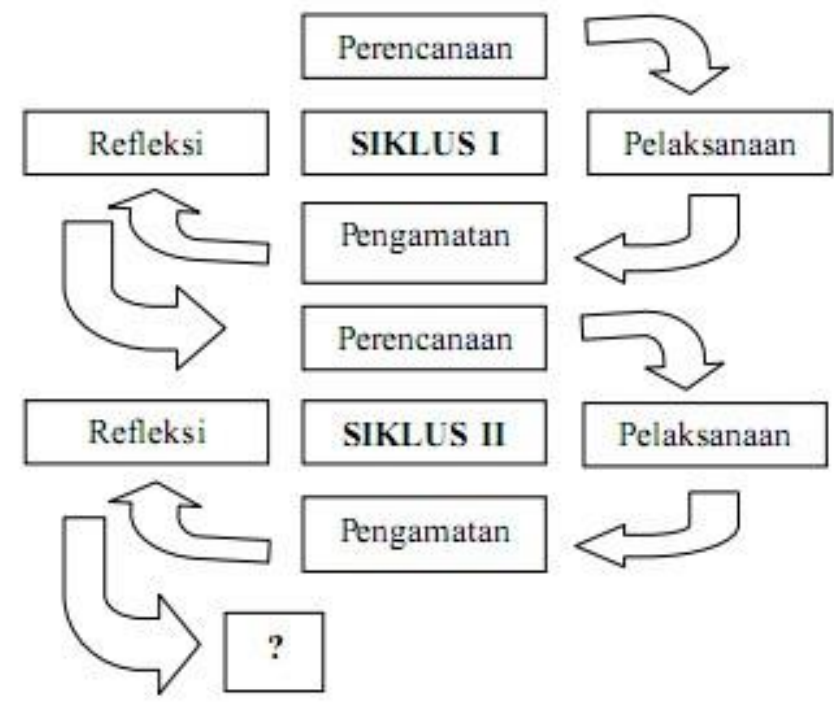

Gambar 2.Rancangan Penelitian Tindakan Kelas Model Kemmis \& Taggart (SuharsimiArikunto, 2008: 16)

Penelitian dilakukan secara kolaboratif dengan guru. Target penelitian ini yaitu apabila dalam siklus pertama tujuan belum tercapai maka akan dilanjutkan dalam siklus kedua dan seterusnya hingga tujuan tercapai.

D. Prosedur Penelitian

Penelitian ini dilaksanakan dalam bentuk siklus sesuai dengan model Kemmis dan Mc Taggart yaitu tahaptahap penelitian tindakan kelas untuk mencapai perubahan dan hasil yang diinginkan.Tahap-tahap yang dimaksud mulai dari tahap perencanaan, pelaksanaan, pengamatan dan refleksi. Kegiatan refleksi akan dilakukan untuk mengetahui keberhasilan dari tindakan yang dilakukan. Apabila pada siklus pertama belum menunjukkan perubahan maka akan dilanjutkan pada siklus kedua dengan perbaikan dari tindakan pada siklus pertama dan begitu seterusnya hingga mencapai hasil yang diinginkan. Adapun langkah-langkah yang ditempuh dalam pelaksanaan penelitian ini adalah sebagai berikut:

\section{Siklus I}

\section{a. Perencanaan}

Pada tahap perencanaan, penulis menyiapkan segala sesuatu yang dibutuhkan saat penelitian yaitu:

1) Menyusun rencana pelaksanaan pembelajaran (RPP)

2) Membuat skenario atau langkahlangkah tindakan yang akan dilakukan.

3) Menentukan perlengkapanperlengkapan yang akan digunakan dalam pelaksanaan pembelajaran dengan Reward and Punishment. 
4) Menetapkan kriteria keberhasilan tindakan.

5) Menyiapkan instrumen penelitian berupa lembar observasi dan pedoman wawancara.

\section{b.Pelaksanaan Tindakan}

Pelaksanaan tindakan disesuaikan dengan rencana pelaksanaan pembelajaran yang telah dibuat sebelumnya. Pelaksanaan pembelajaran yang telah dibuat penulis berperan sebagai guru. Berikut ini adalah langkahlangkah pelaksanaan tindakan yang dilaksanakan dalam pembelajaran mengetik sistem 10 jari dengan Reward and Punishment:

1) Pertemuan pertama

a) Pendahuluan (10 menit)

(1) Salam, do'adan presensi

(2) Guru melakukana persepsi untuk membangkitkan semangat belajar siswa.

(3) Menyampaikan tujuan pembelajaran

b) Kegiatan inti (55 menit)

(1) Guru menyampaikan materi yang akan dipelajari.

(2) Guru mengenalkan metode pembelajaran yang akan digunakan untuk pertemuanpertemuan selanjutnya yaitu pengenalan metode Reward and Punishment beserta langkah- langkahnya.

(3) Metode yang digunakan sama seperti yang sebelumnya yaitu penugasan, guru memberikan penugasan kepada siswa, kemudian siswa menyelesaikannya dengan tambahan pemberian Reward and Punishment bagi siswa yang menyelesaikan penugasan sesuai dengan aturan yang telah disepakati bersama, apabila siswa melanggar aturan maka akan dikenai Punishment. Setiap siswa membawa tugasnya masing-masing dan diketik sesuai dengan aturan mengetik dengan benar.

c) Penutup (15 menit)
(1) Meneliti hasil pekerjaan siswa

(2) Mengumumkan siswa yang mendapatkan Reward dan yang mendapatkan Punishment.

2) Pertemuan Kedua

a) Pembuka (10 menit)

(1) Salam, do'adan presensi

(2) Guru melakukan apersepsi untuk membangkitkan semangat belajar siswa dan menyampaikan tujuan pembelajaran

b) Kegiatan inti (55 menit)

(1) Guru menyampaikan materi yang akan dipelajari.

(2) Guru mengenalkan metode pembelajaran yang akan digunakan untuk pertemuanpertemuan selanjutnya yaitu pengenalan metode Reward and Punishment beserta langkah-langkahnya.

(3) Metode yang digunakan sama seperti yang sebelumnya yaitu penugasan, guru memberikan penugasan kepada siswa, kemudian siswa menyelesaikannya dengan tambahan pemberian Reward and Punishment bagi siswa yang menyelesaikan penugasan sesuai dengan aturan yang telah disepakati bersama, apabila siswa melanggar aturan maka akan dikenai Punishment.

(4) Setiap siswa membawa tugasnya masing-masing dan diketik sesuai dengan aturan mengetik dengan benar.

c) Penutup (20 menit)

(1) Berdoa

(2) Mengumpulkan tugas.

(3) Memberikan siswa pujian yang menaati, mempertahankan dan meningkatkan serta teguran bagi yang melanggar untuk jangan mengulanginya kembali.

(4) Siswa menjawab pertanyaan wawancara 


\section{c. Refleksi dan evaluasi}

Setelah melaksanakan observasi
maka hasil kegiatan observasi
dianalisis bersama, relanjutnya
dilakukan refleksi. $\begin{array}{r}\text { Kemudian } \\ \text { dilakukan diskusi rut }\end{array}$
mengevaluasi hasil pelaksanaan
tindakan, penilaian terhadap proses,
masalah-masalah yang muncul dan
segala hal yang berkaitan dengan
tindakan yang dilakukan. Setelah itu
mencari solusi untuk mengatasi
masalah yang dihadapi. Kegiatan
refleksi bertujuan agar dapat membuat
rencana perbaikan pada siklus
selanjutnya, sehingga hasil yang
diharapkan dapat tercapai pada siklus
selanjutnya. Indikator keberhasilan
siklus yaitu apabila siswa sudah mulai
mengetik dengan benar yaitu dapat
dilihat melalui pengamatan oleh
peneliti.

2. Siklus II dan seterusnya

Siklus II dilaksanakan setelah dilakukan refleksi pada siklus I. Jika pada siklus I ditemukan kekurangan atau belum mencapai kriteria indicator keberhasilan maka perlu ada rancangan ulang yang diperbaiki dan dimodifikasi untuk melakukan siklus yang kedua. Apabila siklus II belum ada peningkatan maka dilakasanakan siklus selanjutnya.

E. Data dan Sumber Data

Jenis data yang dikumpulkan adalah data kualitatif. Data tersebut merupakan hasil yang diperoleh selama pembelajaran meliputi: wawancara, observasi atau pengamatan dan catatan lapangan yang berkaitan dengan pelaksanaan tindakan juga dikumpulkan sebagai data pendukung. Sumber data yang sekaligus sebagai subjek penelitian adalah siswa kelas X OTKP-1 di SMK Negeri 2 Selong.

F. Teknik Pengumpulan Data

Ada beberapa teknik yang dipergunakan untuk mengumpulkan data dalam penelitian ini, teknik tersebut antara lain:

\section{a. Observasi}

Peneliti melakukan observasi dengan cara melakukan pengamatan dan pencatatan mengenai pelaksanaan pembelajaran dikelas tanpa mengganggu jalannya kegiatan belajar mengajar. Observasi dilakukan dengan menggunakan lembar observasi yang telah dipersiapkan dan membuat catatan tentang kejadian-kejadian selama pembelajaran berlangsung. Hasil observasi ini digunakan untuk mendapatkan data tentang prestasi belajar siswa, penerapan metode reward and punishment selama kegiatan belajar mengajar berlangsung.

b. Wawancara

Wawancara ini ditujukan kepada guru mata pelajaran serta siswa kelas $\mathrm{X}$ OTKP-1 untuk mengetahui prestasi belajar siswa dan tanggapan guru danjuga siswa mengenai penggunaan metode Reward and Punishment.

c. Dokumentasi

Teknik dokumentasi dalam penelitian ini merupakan suatu teknik pengumpulan data dengan menghimpun dan menganalisis dokumen- dokumen yang mendukung penelitian. Data tersebut diperoleh dari hasil laporanlaporan dan keterangan-keterangan tertulis, tergambar, terekam, maupun tercetak seperti kondisi fisik sekolah, jenis-jenis ruang, visi misi SMK Negeri 2 Selong, data siswa, capaian hasil belajar siswa, kegiatan pembelajaran, silabus dan RPP serta dokumen SMK Negeri 2 Selong yang kemudian dipilih sesuai dengan focus permasalahan dalam penelitian.

G. Instrumen Penelitian

Instrumen penelitian adalah sarana yang digunakan untuk menghasilkan data yang akurat dan memudahkan peneliti untuk mengolahnya. Adapun instrument yang digunakan dalam penelitian ini adalah:

1. Lembar observasi

Pedoman observasi merupakan kegiatan pengamatan dan pencatatan sistematis terhadap segala hal yang terjadi di lapangan. Kisi-kisi pedoman observasi prestasi belajar siswa dengan menggunakan metode Reward and Punishment pada pembelajaran Sistem Mengetik 10 Jari dapat dilihat melalui tabel 1yaitu: 
Tabel 1. Kisi-kisi Pedoman Observasi

\begin{tabular}{|c|c|c|}
\hline NO & Kategori & Aspek yang diamati \\
\hline \multirow{5}{*}{1.} & \multirow{5}{*}{$\begin{array}{l}\text { Kegiatan } \\
\text { Pembelajaran mengetik } \\
\text { sistem } 10 \text { jari } \\
\text { menggunakan metod } \\
\text { ereward and } \\
\text { punishment }\end{array}$} & 1.Keseriusan siswa menerima materi \\
\hline & & 2.Respon siswa terhadap penjelasan guru \\
\hline & & $\begin{array}{l}\text { 3.Keaktifan siswa dalam kegiatan } \\
\text { pembelajaran }\end{array}$ \\
\hline & & 4.Kedisiplinan mengetik \\
\hline & & 5.Hasil Praktikum \\
\hline \multirow{3}{*}{2.} & \multirow{3}{*}{$\begin{array}{l}\text { Prestasisiswa } \\
\text { dalam pembelajaran } \\
\text { mengetik sistem } 10 \\
\text { jari }\end{array}$} & 1.Penyelesaikan tugas dengan tepat \\
\hline & & 2.Cara mengetik siswa (penilaian proses) \\
\hline & & 3. Ketepatan posisijari siswa \\
\hline
\end{tabular}

\section{Pedoman wawancara}

Sebelum melaksanakan penelitian, pedoman wawancara dibuat detail agar mempermudah wawancara selama penelitian berlangsung. Pedoman wawancara berisi butirbutir pertanyaan yang akan diajukan saat wawancara. Pedoman wawancara diajukan kepada siswa kelas X OTKP-1di SMK Negeri 2 Selong.

Kisi-kisi wawancara prestasi belajar siswa dengan menggunakan metode Reward and Punishment pada pembelajaran Sistem Mengetik 10 Jari dapat dilihat melalui tabel 2, yaitu:

Tabel 2. Kisi-kisi wawancara untuk Guru dan Siswa

\begin{tabular}{|c|c|c|}
\hline Sumber & Indikator Wawancara & $\begin{array}{c}\text { No.Ite } \\
\mathrm{m}\end{array}$ \\
\hline \multirow{8}{*}{ Guru } & 1. Prestasibelajar siswa & 1 \\
\hline & 2.Metode pembelajaran yang sering digunakanguru & 2 \\
\hline & 3.Pendapat guru tentang metode Reward and Punishment & 3 \\
\hline & $\begin{array}{l}\text { 4.Penerapan metode reward and punishment dapat meningkatkan } \\
\text { motivasi siswa. }\end{array}$ & 4 \\
\hline & 5.Opini guru terhadap penerapan metode reward and punishment & 5 \\
\hline & 6.Manfaat penerapan metode reward and punishmet & 6 \\
\hline & $\begin{array}{l}\text { 7.Hambatan yang dihadapi dalam penerapan metode reward and } \\
\text { punishment yang dilaksanakan }\end{array}$ & 7 \\
\hline & $\begin{array}{l}\text { 8.Solusi dalam mengatasi hambatan pelaksanaan pembelajaran } \\
\text { dengan metode reward and punishment }\end{array}$ & 8 \\
\hline \multirow{6}{*}{ Siswa } & 1.Pendapat tentang mengetik sistem 10 jari & 1 \\
\hline & $\begin{array}{l}\text { 2.Metode pembelajaran yang sering digunakan oleh guru saat } \\
\text { mengetik sistem } 10 \text { jari }\end{array}$ & 2 \\
\hline & 3. Pendapat siswa tentang metode reward and punishment & 3 \\
\hline & $\begin{array}{l}\text { 4.Penerapan metode reward and punishment dalam proses } \\
\text { pembelajaran }\end{array}$ & 4 \\
\hline & 5.Pendapat siswa terhadap penerapan reward and punishment & 5 \\
\hline & 6.Manfaat penerapan reward and punishment & 6 \\
\hline
\end{tabular}




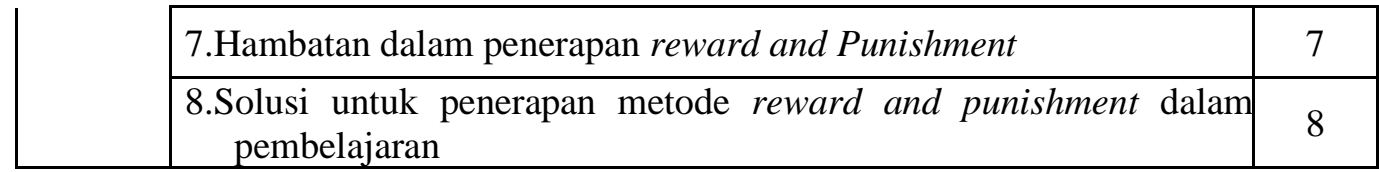

3.Pedoman Dokumentasi

Pedoman dokumentasi berisi catatan atau hasil-hasil laporan dan keterangan-keterangan secara tertulis, tergambar, maupun tercetak mengenai hal-hal yang dibutuhkan untuk melengkapi dan memperkuat jawaban pada hasil observasi dan wawancara. Pedoman dokumentasi digunakan untuk memudahkan peneliti dalam memperoleh data yang telah tersedia dalam bentuk arsip/dokumen, yang tidak didapat dari teknik lainnya. Informasi yang diperlukan dari metode ini adalah visi dan misi SMK Negeri 2 Selong, jenis-jenis ruangan beserta jumlah ruangannya, RPP, data siswa, capaian hasil belajar siswa, kegiatan pembelajaran, catatan lapangan dan foto proses belajar mengajar.

H. Teknik Keabasahan Data

Menguji keabsahan data dapat diketahui dengan cara triangulasi data. Penelitian ini menggunakan triangulasi metode. Triangulasi metode dapat dilakukan dengan mengecek derajat kepercayaan dari beberapa teknik pengumpulan data.Hasil tersebut dapat dicapai dengan jalan membandingkan data hasil observasi dengan data hasil wawancara.

\section{Teknik Analisis Data}

\section{a. Reduksi data}

Reduksi data digunakan untuk mengelompokkan data yang diperoleh dari hasil observasi, wawancara, dan dokumentasi selama penelitian. Datadata yang diperoleh kemudian dikelompokkan berdasarkan kebutuhan seperti data mengenai prestasi belajar.

b. Penyajian Data

Penyajian data dilakukan setelah proses reduksi data selesai dilakukan, data disajikan dalam bentuk teks yang bersifat naratif (saling berhubungan) yang diperjelas melalui table dan diagram/bagan pemaparan data berfungsi untuk membantu kita memahami apa yang terjadi dan merencanakan tindakan selanjutnya.

c. Verifikasi dan pengambilan kesimpulan

Data yang diperoleh disajikan dalam bentuk tulisan, kemudian ditarik kesimpulan dengan menggunakan metode induktif, yaitu berangkat dari hal- hal yang bersifat khusus untuk memperoleh kesimpulan umum yang objektif. Verifikasi bisa berupa pemikiran kembali yang melintas dalam pemikiran peneliti saat mengadakan pencatatan, atau bisa berupa suatu tinjauan ulang terhadap catatan-catatan di lapangan.

Analisis data yang digunakan yaitu menggunakan perhitungan persentase dengan rumus sebagai berikut:

$$
N P=\frac{R}{S M} \times 100 \%
$$

Keterangan:

$\mathrm{NP}=$ Nilai persentase yang dicari

$\mathrm{R}=$ Skor mentah yang diperoleh siswa

$\mathrm{SM}=$ Skor maksimum ideal

$100=$ Bilangan tetap

(Ngalim purwanto, 2002:102).

J. Kriteria Keberhasilan Tindakan

Kriteria merupakan patokan untuk mentukan keberhasilan suatu kegiatan atau program. Suatu kegiatan atau program dikatakan berhasil manakala mampu mencapai criteria yang telah ditentukan. Zainal Aqib (2009:41) menyatakanbahwa, "criteria tingkat keberhasilan belajar siswa sebesar $75 \%$ sudah termasuk tinggi. Oleh karena itu penelitian ini dikatakan berhasil apabila hasil rata-rata nilai belajar minimal mencapai 75\%".

\section{HASIL PENELITIAN DAN PEMBAHASAN}

A. Pembahasan Hasil Penelitian

Penelitian ini dilaksanakan pada tanggal 01 September sampai dengan 31 
Oktober 2020 dengan subjek penelitian adalah siswa kelas X OTKP-1 yang berjumlah 32orang. Pada penelitian ini guru yang bertindak sebagai peneliti mencoba menerapkan metode dengan pemberian reward and panishmant guna meningkatkan hasil belajar kimia siswa.Tahap-tahap yang digunakan adalah tahap-tahap pemecahan masalah yang terdiri dari 4 (empat) tahap yaitu analisis, perencanaan, perhitungan, dan pengecekan.Secara garis besar penelitian tindakan kelas yang telah dilaksanakan terdiri dari 3 (tiga) siklus, masing-masing siklus terdiri dari 4 (empat) tahapan yakni perencanaan, pelaksanaan, pengamatan, dan refleksi.

a) Hasil Penelitian Siklus 1

Hasil Kegiatan Pembelajaran Menggunakan Metode Reward and Punishment

\section{Prestasi Belajar}

Prestasi belajar diukur dengan melakukan pengamatan prestasi belajar siswa pada saat kegiatan pembelajaran siklus I. Selain itu, pengukuran prestasi belajar juga diukur berdasarkan hasil wawancara dengan guru dan siswa. Berdasarkan hasil wawancara dengan guru dan siswa diketahui bahwa penerapan metode reward and punishment pada pembelajaran mengetik system 10 jari dapat meningkatkan prestasi belajar siswa karena siswa menjadi lebih semangat. Selain itu, terlihat pula dari seluruh siswa (32 siswa) hanya16 siswa termotivasi mengikuti pembelajaran mengetik sistem 10 jari. Siswa yang termotivasi mengikuti pembelajaran mengetik sistem 10 jari ditunjukkan dari:

1) Siswa senang memberi tanggapan dan jawaban terhadap pernyataan yang diberikan guru.

2) Siswa senang membantu teman yang kesulitan dalam pembelajaran mengetik sistem 10 jari.

3) Siswa antusias dalam mengikuti pembelajaran mengetik sistem 10 jari

4) Siswa segera membuka buku sumber lainuntuk mencari jawaban ketikaguru melakukan tanyajawab.

Sementara itu, sebanyak 16siswa terlihat belum termotivasi mengikuti pembelajaran mengetik sistem10 jari. Hal ini terbukti dari siswayang masih mengetik sembarangan. Oleh karena itu, sebelum pelajaran dimulai handphone siswa disita dan setelah selesai pelajaran handphone dikembalikan kembali ke siswa. Ditinjau dari pendapat guru mengatakan bahwa pada pertemuan pertama penerapan metode reward and punisment dalam proses pembelajaran mengetik system 10 jari sudah berjalan dengan baik meskipun hanya ada satu siswa yang mampu menerapkan mengetik 10 jari dengan benar. Penerapanmetode reward and punishment bermanfaat bagi siswa karena hasil ketikan para siswa lebih cepat selesai dan hasilnya lebih rapi dari pada mengetik tanpa menggunakan sistem 10 jari.

b) Nilai Keterampilan Mengetik

Sistem10 Jari

Nilai

keterampilan

mengetiksistem 10 jari diukur berdasarkan lembar pengamatan Penilaian keterampilan mengetik sistem 10 jari berdasarkan pada aspek kecermatan, ketepatan huruf, dan ketepatan waktu. Penilaian dari masing-masing aspek tersebut diberikan kemudian dirata-rata dan selanjutnya diperoleh hasil akhir. Berikut adalah data nilai keterampilan mengetik sistem 10 jari siklus I dapat dilihat melalui tabel 6 , yaitu: 
Tabe 16. Data Nilai Keterampilan Mengetik Sistem 10 Jari Siklus I

\begin{tabular}{|c|c|c|c|c|c|c|}
\hline \multirow{3}{*}{ No. } & \multirow{3}{*}{ Siswa } & \multicolumn{3}{|c|}{ Praktik Individu } & \multirow{3}{*}{ Nilai } & \multirow{3}{*}{ Keterangan } \\
\hline & & \multirow{2}{*}{$\begin{array}{c}\text { Ke- } \\
\text { cermat- } \\
\text { an } \\
\end{array}$} & \multicolumn{2}{|c|}{ Ketepatan } & & \\
\hline & & & Huruf & Waktu & & \\
\hline 1. & Agil Arya & 75 & 65 & 70 & 70.0 & Tidak Tuntas \\
\hline 2. & Agusriadi & 75 & 76 & 75 & 75.3 & Tuntas \\
\hline 3. & Baiq Arla Uling Hidayati & 74 & 65 & 70 & 69.7 & Tidak Tuntas \\
\hline 4. & Baiq Desi Aoliya Pratami & 75 & 73 & 77 & 75.0 & Tuntas \\
\hline 5. & Baiq Rida Nur Arafah & 78 & 76 & 73 & 75.7 & Tuntas \\
\hline 6. & Desita Sal Sabila & 76 & 75 & 75 & 75.3 & Tuntas \\
\hline 7. & Dewi Mariana & 75 & 75 & 85 & 78.3 & Tuntas \\
\hline 8. & Dewi Selvia Agustina & 85 & 80 & 85 & 83.3 & Tuntas \\
\hline 9. & Egiana Astuti & 80 & 75 & 80 & 78.3 & Tuntas \\
\hline 10. & Fathurro Ziki & 70 & 75 & 75 & 73.3 & Tidak Tuntas \\
\hline 11. & Haikal Zulfi Maulana & 75 & 80 & 70 & 75.0 & Tuntas \\
\hline 12. & Haris Kasagi & 80 & 80 & 80 & 80.0 & Tuntas \\
\hline 13. & Hopipah Indar Suryani & 65 & 70 & 75 & 70.0 & Tidak Tuntas \\
\hline 14. & Intan Liyana Anwar & 80 & 82 & 80 & 80.7 & Tuntas \\
\hline 15. & Laili Sopiatul Mawa & 70 & 75 & 72 & 72.3 & Tidak Tuntas \\
\hline 16. & Lalu Deri Suciawan & 70 & 79 & 75 & 74.7 & Tidak Tuntas \\
\hline 17. & M. Khairul Azmi & 80 & 77 & 75 & 77.3 & Tuntas \\
\hline
\end{tabular}

\begin{tabular}{|l|l|c|c|c|c|c|}
\hline \multirow{2}{*}{ No. Siswa } & \multirow{2}{*}{} & \multicolumn{2}{|c|}{ Praktik Individu } & \multirow{2}{*}{ Nilai } & \multirow{2}{*}{ Keterangan } \\
\cline { 3 - 6 } & & $\begin{array}{c}\text { Ke- } \\
\text { cermat- } \\
\text { an }\end{array}$ & $\begin{array}{c}\text { Ketepatan } \\
\text { Huruf }\end{array}$ & Waktu & & \\
\hline 18. & M. Ahyani & 80 & 85 & 75 & 80.0 & Tuntas \\
\hline 19. & Maulida Afni & 70 & 75 & 73 & 72.7 & Tidak Tuntas \\
\hline 20. & Muhamad Aldi Saputra & 75 & 72 & 75 & 74.0 & Tidak Tuntas \\
\hline 21. & Muhammad Nazri & 72 & 80 & 78 & 76.7 & Tuntas \\
\hline 22. & Nurul Fitriani & 76 & 75 & 80 & 77.0 & Tuntas \\
\hline 23. & Nurul Mardiana & 77 & 75 & 80 & 77.3 & Tuntas \\
\hline 24. & Ria Rizkika & 70 & 75 & 80 & 75.0 & Tuntas \\
\hline 25. & Rian Angga Wijaya & 68 & 68 & 70 & 68.7 & Tidak Tuntas \\
\hline 26. & Riska Dwi Sagita Rinjani & 68 & 70 & 70 & 69.3 & Tidak Tuntas \\
\hline 27. & Samsul Hendra Yadi & 70 & 70 & 68 & 69.3 & Tidak Tuntas \\
\hline
\end{tabular}




\begin{tabular}{|c|l|c|c|c|c|l|} 
28. & Sarif Rizki Isrori & 70 & 68 & 70 & 69.3 & Tidak Tuntas \\
\hline 29. & Sri Ikzan Apriandini & 70 & 70 & 75 & 71.7 & Tidak Tuntas \\
\hline 30. & Wahyu Zaki Aldi & 68 & 70 & 70 & 69.3 & Tidak Tuntas \\
\hline 31. & Wina Agustina & 65 & 70 & 60 & 65.0 & Tidak Tuntas \\
\hline 32. & Yulia Marlina Hidayati & 70 & 68 & 70 & 69.3 & Tidak Tuntas \\
\hline \multicolumn{2}{|r|}{ Mean } & 73.5 & 74.0 & 74.6 & 74.0 & Tidak Tuntas \\
\hline
\end{tabular}

Sumber:Data Nilai UlanganBulan September 2020

Berdasarkan table 6 di atas diketahui bahwa pada saat siklusI nilai keterampilan siswa dalam mengetik system 10 jari yang termasuk dalam kategori tidak tuntas sebanyak 16 siswa (50\%) dan 16 siswa dinyatakan tuntas $(50 \%)$. Menurut perhitungan tersebut, nilai rata-rata keterampilan mengetik sistem 10 jari kelas X OTKP-1 SMK Negeri 2 Selong adalah 74 dan termasuk dalam kategori tidak tuntas. Meskipun ada 16 siswa yang dinyatakan tuntas pada siklus I,namun hanya ada 2 siswa yang diberi reward, karena siswa tersebut mendapatkan nilai tertinggi.

d. Refleksi

Berdasarkan pengamatan yang dilakukan dan bersama guru melakukan refleksi berkaitan dengan proses dan hasil kegiatan pembelajaran yang terjadi pada siklus I. Pada proses kegiatan pembelajaran siklus I menggunakan metode reward and punishment terdapat beberapa kelebihan dan kekurangan. Pada tahap refleksi ini, menanyakan kelebihan dan kekurangan selama proses pembelajaran pada guru dan siswa. Kelebihan dan kekurangan tersebut diantaranya:

1)Kelebihan

a) Penerapan metode reward and punishment pada pembelajaran mengetik sistem10 jari dapat meningkatkan prestasi belajar beberapa siswa karena siswa menjadi lebih semangat.

b) Penerapan metode reward and punishment bermanfaat bagisiswa karena hasil ketikan para siswa lebih cepat selesai dan hasilnya lebih rapi dari pada mengetik tanpa menggunakan sistem 10 jari.

c) Adanya penghargaan yang diberikan kepada siswa yang berprestasi membuat siswa yang menerima penghargaan menjadi senang dan siswa- siawa yang lain lebih termotivasi untuk menjadi lebih baik dalam mengetik sistem 10 jari.

2) Kekurangan

a) Pada saat pengambilan dokumentasi selama kegiatan pembelajaran meminta bantuan 3 teman yang bertugas mengamati minat siswa, merekam kegiatan pembelajaran, dan mengambil foto. Namun saat observer mereka mau mengambil foto siswa selama kegiatan pembelajaran, terdapat siswa yang menutupi wajahnya dengan buku. Bahkan ada beberapa siswa lain yang berpose saat kamera menghampiri siswa tersebut, akibatnya siswa menjadi tidak focus terhadap pembelajaran.

b) Siswa tidak terbiasa mengetik system 10 jari dan computer yang dipakai kadang eror sehingga menghambat proses pembelajaran.

c) Siswa terlihat cepat lelah, karena belum terbiasa dan semakin lama dalam mengetik.

d) Siswa belum mengetahui penataan jari-jari dengan benar pada keyboard saat mengetik sistem 10 jari.

\section{c) Hasil Penelitian Siklus II}


a. Hasil Kegiatan Pembelajaran

Menggunakan Metode Reward and

Punishment

a) Prestasi Belajar

Prestasi belajar diukur dengan melakukan pengamatan prestasi belajar siswa pada saat kegiatan pembelajaran siklus II. Selain itu, pengukuran prestasi belajar juga diukur berdasarkan hasil wawancara dengan guru dansiswa. Berdasarkan hasil wawancara dengan guru dan siswa diketahui bahwa penerapan metode reward and punishment pada pembelajaran mengetik sistem 10 jari dapat meningkatkan prestasi belajar siswa karena siswa menjadi lebih semangat. Selain itu, terlihat pula dari seluruh siswa (32 siswa) semua siswa termotivasi mengikuti pembelajaran mengetik sistem 10 jari. Sebelum adanya penerapan metode reward and punishment, siswa menilai pembelajaran mengetik system 10 jari membosakan karena tidak bervariasi dan siswa diminta untu kmengetik terus selama pembelajaran berlangsung. Guru juga mengatakan bahwa pada pertemuan kedua penerapan metode reward and punishment dalam proses pembelajaran mengetik sistem 10 jari sudah berjalan dengan baik dan sudah banyak siswa yang mampu menerapkan mengetik 10 jari dengan benar. Penerapan metode reward and punishment bermanfaat bagi siswa karena hasil ketikan para siswa lebih cepat selesai dan hasilnya lebih rapi daripada mengetik tanpa menggunakan sistem 10 jari.

b) Nilai Keterampilan Mengetik Sistem10 Jari

Nilai keterampilan mengetik system 10 jari diukur berdasarkan lembar pengamatan Penilaian keterampilan mengetik system 10 jari berdasarkan pada aspek kecermatan, ketepatan huruf, dan ketepatan waktu. Penilaian dari masing-masing aspek tersebut diberikan kemudian dirata-rata dan selanjutnya diperoleh hasil akhir. Berikut adalah data nilai keterampilan mengetik system 10 jari siklus II dapat dilihat melalui table 7 , yaitu:

Tabel 7. Data Nilai Keterampilan Mengetik Sistem 10 Jari Siklus II

\begin{tabular}{|c|c|c|c|c|c|c|}
\hline \multirow{3}{*}{ No. } & \multirow{3}{*}{ Siswa } & \multicolumn{3}{|c|}{ Praktik Individu } & \multirow{3}{*}{ Nilai } & \multirow{3}{*}{ Keterangan } \\
\hline & & \multirow{2}{*}{$\begin{array}{l}\mathrm{Ke}- \\
\text { cermat- } \\
\text { an } \\
\end{array}$} & \multicolumn{2}{|c|}{ Ketepatan } & & \\
\hline & & & Huruf & Waktu & & \\
\hline 1. & Agil Arya & 75 & 70 & 75 & 73.3 & Tidak Tuntas \\
\hline 2. & Agusriadi & 80 & 83 & 80 & 81.0 & Tuntas \\
\hline 3. & Baiq Arla Uling Hidayati & 80 & 75 & 80 & 78.3 & Tuntas \\
\hline 4. & Baiq Desi Aoliya Pratami & 83 & 80 & 80 & 81.0 & Tuntas \\
\hline 5. & Baiq Rida Nur Arafah & 82 & 80 & 78 & 80.0 & Tuntas \\
\hline 6. & Desita Sal Sabila & 82 & 80 & 80 & 80.7 & Tuntas \\
\hline 7. & Dewi Mariana & 85 & 85 & 84 & 84.7 & Tuntas \\
\hline 8. & Dewi Selvia Agustina & 95 & 90 & 94 & 93.0 & Tuntas \\
\hline 9. & Egiana Astuti & 80 & 83 & 85 & 82.7 & Tuntas \\
\hline 10. & Fathurro Ziki & 85 & 80 & 77 & 80.7 & Tuntas \\
\hline 11. & Haikal Zulfi Maulana & 80 & 75 & 78 & 77.7 & Tuntas \\
\hline
\end{tabular}


Vol. 10. No. 1. Tahun 2022

\begin{tabular}{|l|l|r|r|r|r|l|} 
12. & Haris Kasagi & 80 & 75 & 75 & 76.7 & Tuntas \\
13. & Hopipah Indar Suryani & 75 & 75 & 78 & 76.0 & Tuntas \\
14. & Intan Liyana Anwar & 90 & 90 & 92 & 90.7 & Tuntas \\
\hline
\end{tabular}

\begin{tabular}{|c|c|c|c|c|c|c|}
\hline \multirow{3}{*}{ No. } & \multirow{3}{*}{ Siswa } & \multicolumn{3}{|c|}{ Praktik Individu } & \multirow{3}{*}{ Nilai } & \multirow{3}{*}{ Keterangan } \\
\hline & & \multirow{2}{*}{\begin{tabular}{|c|} 
Ke- \\
cermat- \\
an \\
\end{tabular}} & \multicolumn{2}{|c|}{ Ketepatan } & & \\
\hline & & & Huruf & Waktu & & \\
\hline 15. & Laili Sopiatul Mawa & 85 & 80 & 80 & 81.7 & Tuntas \\
\hline 16. & Lalu Deri Suciawan & 78 & 79 & 78 & 78.3 & Tuntas \\
\hline 17. & M. Khairul Azmi & 85 & 84 & 82 & 83.7 & Tuntas \\
\hline 18. & M. Ahyani & 85 & 90 & 90 & 88.3 & Tuntas \\
\hline 19. & Maulida Afni & 85 & 80 & 73 & 79.3 & Tuntas \\
\hline 20. & Muhamad Aldi Saputra & 80 & 78 & 75 & 77.7 & Tuntas \\
\hline 21. & Muhammad Nazri & 80 & 80 & 78 & 79.3 & Tuntas \\
\hline 22. & Nurul Fitriani & 80 & 80 & 80 & 80.0 & Tuntas \\
\hline 23. & Nurul Mardiana & 85 & 85 & 80 & 83.3 & Tuntas \\
\hline 24. & Ria Rizkika & 85 & 80 & 80 & 81.7 & Tuntas \\
\hline 25. & Rian Angga Wijaya & 75 & 75 & 70 & 73.3 & Tidak Tuntas \\
\hline 26. & Riska Dwi Sagita Rinjani & 76 & 78 & 75 & 76.3 & Tuntas \\
\hline 27. & Samsul Hendra Yadi & 80 & 80 & 80 & 80.0 & Tuntas \\
\hline 28. & Sarif Rizki Isrori & 75 & 70 & 70 & 71.7 & Tidak Tuntas \\
\hline 29. & Sri Ikzan Apriandini & 80 & 77 & 78 & 78.3 & Tuntas \\
\hline 30. & Wahyu Zaki Aldi & 75 & 75 & 70 & 73.3 & Tidak Tuntas \\
\hline 31. & Wina Agustina & 85 & 82 & 80 & 82.3 & Tuntas \\
\hline 32. & Yulia Marlina Hidayati & 85 & 80 & 80 & 81.7 & Tuntas \\
\hline & Mean & 81.6 & 79.8 & 79.2 & 80.2 & Tuntas \\
\hline
\end{tabular}

Sumber: Data Nilai Ulangan Bulan September 2020

Berdasarkan table di atas diketahui bahwa pada saat siklus II nilai keterampilan siswa dalam mengetik system 10 jari yang termasuk dalam kategori tidak tuntas sebanyak 4 siswa (13\%) dan 28 siswa dinyatakan tuntas (88\%). Menurut perhitungan tersebut, nilai rata-rata keterampilan mengetik sistem 10jari kelas $\mathrm{X}$ SMK Negeri 2 Selong siklus II adalah 80,2 dan termasuk dalam kategori tuntas.

\section{d. Refleksi}

Berdasarkan pengamatan yang dilakukan dan bersama guru melakukan refleksi berkaitan dengan proses dan hasil kegiatan pembelajaran yang terjadi pada siklus II. Proses kegiatan pembelajaran siklus II menggunakan metode reward and punishment terdapat beberapa kelebihan dan kekurangan. Pada tahap refleksi ini, menanyakan kelebihan dan 
kekurangan selama proses pembelajaran pada guru dan siswa. Kelebihan dan kekurangan tersebut diantaranya:

1) Kelebihan

a) Penerapan metode reward and punishment pada pembelajaran mengetik system 10 jari dapat meningkatkan prestasi belajar semua siswa karena siswa menjadi lebih semangat.

b) Penerapan metode reward and punishment bermanfaat bagi siswa karena hasil ketikan para siswa lebih cepat selesai bagi siswa yang hafal peletakan jari yang tepat pada saat mengetik.

c) Adanya penghargaan yang diberikan kepada siswa yang berprestasi membuat siswa yang menerima penghargaan menjadi senang dan siswa-siswi yang lain lebih termotivasi untuk menjadi lebih baik dalam mengeti ksistem 10 jari.

d) Metode reward and punishment membuat siswa mengetahui kesalahan dalam mengetik karena guru langsung menegur siswa yang mengetik tanpa menggunakan aturan mengetik sistem 10 jari, sehingga siswa segera memperbaiki kesalahan yang telah dilakukan. e) Metode reward and punishment dinilai siswa lebih menarik dari pada metode ceramah.

f) Siswa lebih percaya diri untuk aktif bertanya ketika menghadapi kesulitan dalam mengetik sistem 10 jari.

2) Kekurangan

a) Masih terlihat beberapa siswa yang belum terbiasa mengetik sistem 10 jari.

b) Siswa dalam mengetiksistem 10 jari membutuhkan waktuyanglama.

c) Beberapa siswa belum terbiasa dengan penataan jari-jari yang benar pada keyboard saat mengetik sistem10 jari.

e. Hasil Kegiatan Pembelajaran Menggunakan Metode Reward and Punishment

Berdasarkan penelitian dapat diketahui bahwa rata-rata nilai keterampilan mengetik 10 jari siswa Kelas X OTKP-1 yang berjumlah 32 siswa yaitu prasiklus sebesar 70,06. Hasil siklus I nilai rata-rata siswa sebesar 74 dan siklus II nilai rata-rata siswa sebesar 80,2. Adapun nilai ratarata siswa dapat dilihat pada table 8 sebagai berikut:

Tabel 8. Rata-rata Nilai Keterampilan Mengetik Sistem 10 Jari Pra Siklus, Siklus I dan Siklus II

\begin{tabular}{|l|c|c|c|c|}
\hline \multicolumn{1}{|c|}{ Indikator } & $\begin{array}{c}\text { Pra } \\
\text { Siklus }\end{array}$ & $\begin{array}{c}\text { Hasil } \\
\text { Siklus I }\end{array}$ & $\begin{array}{c}\text { Target } \\
\text { Akhir } \\
\text { Siklus II }\end{array}$ & $\begin{array}{c}\text { Hasil } \\
\text { Siklus II }\end{array}$ \\
\hline $\begin{array}{l}\text { Rata-rata nilai } \\
\text { keterampilan } \\
\text { mengetik system 10 } \\
\text { jari }\end{array}$ & 70,06 & 74 & 75 & 80,2 \\
\hline
\end{tabular}

Berdasarkan table 8 di atas diketahui bahwa nilai keterampilan mengetik system 10 jari siklus II sudah ada peningkatan dari pratindakan dan siklus I, serta telah melampaui target keberhasilan siklus II. Hasil nilai keterampilan mengetik system 10 jari dengan rata-rata pada prasiklus sebesar 70,06. Melalui kegiatan pembelajaran siklus I menggunakan metod ereward and punishment pada mata pelajaran mengetik system 10 jari dapat meningkatkan rata-rata nilai siswa menjadi 74 dan pada siklus II rata-rata nilai siswa meningkat menjadi 80,2. Peningkatan ini dilihat dari nilai rata-rata siklus II sudah melampaui target yang ditetapkan sebesar 75 .

Selanjutnya pada table di bawah ini disajikan data persentase siswa yang mencapai KKM pada pra siklus sebesar $19 \%$, siklus I sebesar 50\%, dan siklus II sebesar 
92\% dapat dilihat melalui tabel 9 sebagai berikut:

Tabel 9.Persentase Siswa yang Mencapai KKM pada PraSiklus,SiklusI dan Siklus II

\begin{tabular}{|c|c|c|c|c|}
\hline Indikator & $\begin{array}{c}\text { Pra } \\
\text { Siklus }\end{array}$ & $\begin{array}{c}\text { Hasil } \\
\text { Siklus I }\end{array}$ & $\begin{array}{c}\text { TargetAkhir } \\
\text { Siklus II }\end{array}$ & $\begin{array}{c}\text { Hasil } \\
\text { Siklus II }\end{array}$ \\
\hline $\begin{array}{c}\text { Persentase siswa yang } \\
\text { mencapai KKM }\end{array}$ & $31 \%$ & $50 \%$ & $75 \%$ & $88 \%$ \\
\hline
\end{tabular}

Sumber: Data Primer 2019

Berdasarkan table 9 di atas diketahui bahwa jumlah siswa yang mencapai KKM pada prasiklus sebesar $31 \%$ atau 10 siswa dari 32 siswa, pada siklus I siswa yang mencapai KKM sebesar 50\% atau 16 orang dari 32 siswa, dan pada siklus II siswa yang mencapai KKM sebesar $88 \%$ atau 28 orang.

Berdasarkan proses dan hasil kegiatan pembelajaran menggunakan metode reward and punishment pada mata pelajaran mengetik system 10 jari dapat disimpulkan bahwa secara umum proses pembelajaran siklus II sudah berjalan sangat baik dan dapat dikatakan berhasil. Perbaikan atas kekurangan yang terjadi pada kegiatan pembelajaran siklus I sudah terjadi, serta peningkatan yang diharapkan juga sudah terlihat melalui kegiatan pembelajaran siklus II. Terdapat peningkatan prestasi belajar dan keterampilan mengetik system 10 jari, karena dipengaruhi penerapan metode reward and punishment pada mata pelajaran mengetik system 10 jari. Peningkatan prestasi ditunjukkan dari:

1) Siswa tidak mengeluh ketika diberi tugas dari guru terkait pembelajaran mengetik sistem 10 jari.

2) Siswa bertanya kepada guru jika ada hal yang tidak dimengerti.

3) Siswa tetap berkonsentrasi walaupun adasuara gaduh.

4) Siswa tidak melamun ketika pelajaran sedang berlangsung.

5) Siswa tidak membicarakan hal lain dengan teman ketika pelajaran sedang berlangsung.

6) Siswa tidak mengganggu teman lain ketika sedang belajar.

7) Siswa menuliskan hal-hal penting berkaitan dengan pembelajaran mengetik sistem 10 jari

8) Siswa membuat catatan pembelajaran mengetik sistem 10 jari dengan rapi.
9) Siswa membuat pertanyaan yang mendalam mengenai materi yang sedang dibahas.

Berdasarkan pencapaian tersebut, maka penelitian ini dihentikan sampai siklus II.

\section{PEMBAHASAN}

Penelitian ini adalah penelitian tindakan kelas, maka rancangan penelitian ini berupa siklus yang secara garis besar terdiri dari empat bagian, yaitu perencanaan, tindakan, pengamatan, dan refleksi. Berkaitan dengan tahapan tersebut, penelitian yang dilaksanakan dikelas $\mathrm{X}$ SMK Negeri 2 Selong ini terdiri dari dua siklus. Kegiatan pembelajarannya bertujuan untuk meningkatkan prestasi belajar mengetik sistem10 jari siswa kelas X OTKP-1SMK Negeri 2 Selong dengan penerapan metode reward and punishment. Pengambilan data prestasi belajar menggunakan wawancara dan nilai keterampilan mengetik sistem 10 jari menggunakan lembar pengamatan.

Berdasarkan analisis data, prestasi belajar siswa mengalami peningkatan dari siklus I dan siklus II. Pada siklus I menggunakan metode reward and punishment terlihat hanya 16 siswa yang antusias mengikuti pembelajaran mengetiksistem 10 jari. Setelah dilakukan tindakan pada siklus II menggunakan metode reward and punishment terjadi peningkatan prestasi belajar siswa karena Sebagian besar siswa (28 siswa) antusias mengikuti pembelajaran mengetik system 10 jari. Berdasarkan pencapaian prestasi belajar tersebut, maka penelitian ini dihentikan sampai siklus II.

Berdasarkan analisis data diketahui bahwa nilai rata-rata keterampilan mengetik siswa mengalami peningkatan dari siklus I ke siklus II. Adanya peningkatan prestasi siswa dalam pembelajaran mengetik system 10 jari juga meningkatkan nilai keterampilan mengetik system 10 jari. Hasil nilai 
keterampilan mengetik system 10 jar idengan rata-rata pada prasiklus sebesar 70,06. Melalui kegiatan pembelajaran siklus I menggunakan metode reward and punishment pada mata pelajaran mengetik system 10 jari dapat meningkatkan rata-rata nilai siswa menjadi 74 dan pada siklus II rata-rata nilai siswa meningkat menjadi 80,2. Hal ini menunjukkan bahwa nilai rata- rata siklus II sudah melampau target yang ditetapkan sebesar 75. Sedangkan untuk hasil keterampilan siswa dengan persentase jumlah siswa yang mencapai KKM pada prasiklus sebesar $31 \%$; siklus I siswa yang mencapai KKM sebesar 50\%; dan pada siklus II siswa yang mencapai KKM sebesar $88 \%$.

Menurut Djanewar (1994:11), "mengetik adalah suatu pekerjaan yang berupa keterampilan yang sangat didambakan oleh setiap orang yang telah memililki dasar pendidikan umum". Kenyataannya menunjukkan bahwa telah banyak orang yang dapat mengetik dalam praktik seharihari, namun belum semua menguasai atau mempergunakan cara mengetik yang benar. Keterampilan mengetik 10 jari adalah keterampilan yang sangat dibutuhkan bagi seorang pengetikatau paling tidak bagi seorang yang menggunakan alat ketik (keyboard) untuk keperluan mengetik. Selain lebih cepat dalam mengetik karena tidak perlu melihat tombol-tombol pada keyboard, mengetik 10 jari juga lebih efisien.

Pengetik tidak perlu lagi melihat ke tombol keyboard untuk memilih atau mengetik karakter mana yang akan di-inputkan pada metode mengetik 10 jari. Mengetik 10 jari merupakan metode khusus dengan cara menggunakan 10 jari yang ditempatkan pada bagian tertentu pada tombol keyboard. Masing-masing jari menekan karakterter tentu yang ditentukan, sehingga konsep mengetik buta (blind system) dapat diterapkan dan pengetik hanya berfokus padahasil ketikan.

\section{PENUTUP}

\section{A. Kesimpulan}

Berdasarkan hasil penelitian dan pembahasan yang telah diuraikan pada bab sebelumnya, maka dapat disimpulkan bahwa metod ereward and punishment dapat meningkatkan prestasi belajar mengetik system 10 jari pada siswa-siswi kelas $\mathrm{X}$ OTKP-1 SMK Negeri 2 Selong. Hal ini dibuktikan dari nilai keterampilan mengetik sistem 10 jari dengan rata-rata pada prasiklus sebesar 70,06. Melalui kegiatan pembelajaran siklus I menggunakan metode reward and punishment pada mata pelajaran mengetik sistem10 jari dapat meningkatkan rata-rata nilai siswa menjadi 74,0 dan pada siklus II rata-rata nilai siswa meningkat menjadi 80,2. Dimana pada nilai rata-rata siklus II sudah melampaui target yang ditetapkan sebesar 75 . Sedangkan untuk hasil keterampilan siswa dengan persentase jumlah siswa yang mencapai KKM pada prasiklus sebesar 31\% atau 10 siswa dari 32 siswa, siklus I siswa yang mencapai KKM sebesar 50\% atau 16 orang dari 32 siswa, dan pada siklus II siswa yang mencapai KKM sebesar $88 \%$ atau 28 orang dari 32 siswa.

\section{B. Saran}

Berdasarkan hasil penelitian di atas, maka saran yang dapat diajukan adalah sebagai berikut:

1. Bagi Guru

Guru disarankan untuk lebih berinisiatif dalam menggunakan berbagai macam metode pembelajaran inovatif dalam kegiatan pembelajaran dikelas,terutama metode reward and punishment, karena metode ini terbukti mampu meningkatkan prestasi belajar siswa dan nilai keterampilan mengetik sistem 10 jari.

2. Bagi Siswa

Siswa disarankan untuk meningkatkan prestasi belajar dengan cara membiasakan diri untuk lebih disiplin dalam mengetik sistem 10 jari, sehingga siswa dapat mengetik dengan cara yang benar dan tepat dan prestasi belajar siswa dapat meningkat.

3. Bagi Sekolah

Pihak sekolah disarankan untuk menambah dan menyediakan computer dalam kondisi bagus dan tidak error sesuai dengan jumlah siswa agar siswa tidak bergantian pada saat mengikuti mata pelajaran mengetik system 10 jari. Pihak sekolah juga disarankan untuk menyediakan software 10 jari, sehingga dapat memudahkan siswa dalam mempelajari mengetik sistem 10 jari.

4. Bagi Peneliti Selanjutnya 
Peneliti selanjutnya sebaiknya menggunakan metode pengumpulan data menggunakan kuesioner untuk mengetahui prestasi belajar siswa, sehingga didapatkan gambaran kondisi awal yang akurat/sahih.

\section{DAFTAR PUSTAKA}

Arikunto, Suharsimi dkk, (2008).Penelitian Tindakan Kelas. (Jakarta: Bumi Aksara)

\section{Anonim, Pembelajaran Dengan Methode} Tutor Sebaya. (blog). http://baliteacher. blogspot.com/2010/02/pembelajaran -dengan-methode-tutor-teman.html, diakses tanggal 25 September 2013, pukul 12.17

Anonim, MS Word 1-Pengenalan MS Word 2007, (blog), http://aridiana.staff. uns.ac.id/2009/08/27/ms-word-1/, diakses tanggal 28 September 2013, pukul 9.26

Anonim, Peer Group, (web), http://en.wikipedia.org/wiki/Peer_gr oup, diakses tanggal 28 September 2013, pukul 9.27

Anonim, Rancangan Proposal PTK, http://ahyaninn.files.wordpress.com/ 2011/07/bab-iii.docx, (blog), diakses tanggal 28 September 2013, pukul 10.53

Edukasi, Media, Pola-pola Belajar Oleh Gagne, (blog), http://mediaedukasiku. blogspot.com/p/pola-pola-belajarsiswa-oleh-gagne.html, diakses tanggal 25 September 2013, pukul 11.47

Saputra, Hardiman, Pola Belajar Tutor Sebaya, (blog), http://hardymath. blogspot .com/2012/03/pola-belajartutor-sebaya.html, diakses tanggal 24 September 2013, pukul 11.28
Slameto, (1995), Belajar dan Faktor-faktor yang Mempengaruhinya, (Jakarta:Rineka Cipta)

Sugiyono, (2002), Metode Penelitian Pendidikan: Pendekatan Kuantitatif, Kualitatif danR \& B, (Bandung: Alfabeta)

Syaiful Sagala, (2003), Konsep dan Makna Pembelajaran, (Bandung: Alfabeta)

Suprihatiningrum, J, (2013). Strategi Pembelajaran : Teori dan Aplikasi, (Jogjakarta: Ar-Ruzz Media)

Wiriaatmadja, R, (2012). Metode Penelitian Tindakan Kelas, (Bandung: PT. Remaja Rosdakarya)

Yudhistira, D, (2013). Menulis Penelitian Tindakan Kelas Yang Apik (Asli PerluIlmiah Konsisten), (Jakarta: PT. Gramedia Widiasarana Indonesia) 